\title{
A humán HLTF fehérje HIRAN doménjének strukturális és funkcionális vizsgálata
}

\author{
Ph.D. értekezés tézisei
}

Balogh Dávid

Témavezetö: Dr. Haracska Lajos

Tudományos főmunkatárs

Biológia Doktori Iskola

Szegedi Tudományegyetem Természettudományi és

Informatikai Kar

MTA Szegedi Biológiai Kutatóközpont

Genetikai Intézet

2016.

Szeged 


\section{Bevezetés}

A sejtjeinkben található örökítőanyagot folyamatosan különböző károsító hatások érik. Ide tartozik az UV sugárzás, a dohányfüst, az alkohol, a kemikáliák és az anyagcsere-folyamatok során keletkezett reaktív oxigén gyökök, amelyek megváltoztatják a DNS szerkezetét. Ennek kivédése érdekében számos DNShibajavító útvonal alakult ki. Ezek a mechanizmusok folyamatosan helyreállítják a DNS lánc eredeti struktúráját, mégis akadnak olyan hibák, amelyek nem kerülnek kijavításra a sejtciklus $\mathrm{S}$ fázisáig. Ekkor a replikációs villa leállását, ennek következtében kettősszálú DNS-töréseket, kromoszomális átrendeződéseket, végső esetben a sejt halálát okozhatják. Ennek elkerülésére alakult ki a DNShibatolerancia útvonal, amely különböző mechanizmusok révén képes a replikációs villa mentésére.

Az útvonal első lépése a polimerázok processzivitási faktoraként azonosított PCNA molekula 164-es lizinjének monoubikvitilálása a Rad6/Rad18 komplex által. Ennek következtében a replikatív polimeráz lecserélődhet egy, a hiba átírására képes alternatív polimerázra. Egy másik, hibamentes átírást biztosító mechanizmus során a monoubikvitilált PCNA molekulát az Mms2/Ubc13/HLTF komplex az ubikvitin 63-as lizinjén keresztül poliubikvitilálja, aminek következtében a HLTF fehérje a replikációs villát képes visszafordítani. Az így létrejött DNS szerkezeten a hibával szemben lévő szál a már újonnan szintetizált 
utód szálról íródhat át. Harmadik lehetőségként a hiba alternatív templátváltás révén is áthidalásra kerülhet.

Kutatásaink során a DNS-hibatolerancia útvonal funkciójának és szabályozásának pontos megértésére törekszünk. Ezen belül is a HLTF fehérje aktivitásainak, szabályozó mechanizmusának minél pontosabb feltárása a célunk. A HLTF fehérjét transzkripciós faktorként és tumorszupresszorként azonosították. Vastagbél-tumorok jelentős százalékában promótere hipermetilált, vagy a fehérje csonkolt formája expresszálódik. A HLTF fehérje jelenleg ismert aktivitásainak döntő többségét kutatócsoportunk tárta fel. A fehérje rendkívül fontos szerepet játszik a genom stabilitásának megörzésében. Csökkent expressziója DNS mutációk felhalmozódásához és genomi instabilitáshoz vezet. Doménszerkezete jól ismert, rendelkezik egy RING típusú ubikvitin ligáz doménnel, valamint a kettősszálú DNS-transzlokáz funkcióért felelős helikáz doménekkel. HIRAN doménjének szerepe azonban máig nem tisztázott. 


\section{Célkitüzések}

Kísérleteink során a következő célokat tüztük ki:

1.) HIRAN domén mutáns HLTF fehérjéket hozunk létre, majd megvizsgáljuk a mutációk hatását.

2.) Teszteljük a tisztított fehérjék ligáz illetve helikáz aktivitását, hogy kizárhassuk az esetleges strukturális mutációkat.

3.) Megvizsgáljuk, hogy a HIRAN domén szerepet játszhat-e a HLTF replikációs villa-visszafordító aktivitásában.

4.) Érzékenységi kísérlettel illetve comet esszével megvizsgáljuk a mutáns fehérjék in vivo funkcióját különböző DNS károsító ágensekkel szemben.

5.) HIRAN domént tisztítunk és megvizsgáljuk, tud-e DNS-t kötni, és ha igen, milyen DNS szerkezetre specifikus a kötés. 


\section{Alkalmazott módszerek}

1. Restrikciós emésztés, ligálás

2. PCR reakció

3. LR reakció

4. Plazmidok klónozás

5. Baktérium transzformálás

6. Plazmidtisztítás baktériumból

7. Élesztő transzformálás

8. Fehérjék tisztítása

9. Poliakrilamid gél elektroforézis

10. Western blot analízis

11. DNS szubsztrát hibridizálás

12. Replikációs villa-visszafordító esszé

13. Gél shift, és DNS kompetíciós kísérletek

14. PCNA ubikvitilációs kísérlet

15. ATPáz esszé

16. Sejten belüli fehérje lokalizáció vizsgálata

17. BrdU comet esszé

18. UV érzékenységi kísérlet 


\section{Az eredmények összefoglalása}

\section{HIRAN domén mutáns HLTF fehérjék létrehozása és in vitro aktivitás tesztelése}

A HIRAN domén in vitro vizsgálatához elsöként kolaborátoraink segítségével meghatároztuk a HIRAN domén háromdimenziós szerkezetét. A szerkezetből kiderült, hogy a HLTF HIRAN doménje nagy valószínüséggel képes DNS kötésre. Sikerült meghatároznunk azokat a legfontosabb aminosavakat is, amik ezért a kötésért felelősek lehetnek. Ezek ismeretében létrehoztunk egy HIRAN domén deléciós mutáns, valamint egy kettős pontmutáns HLTF fehérjét. A fehérjéket élesztőben túltermeltettük, majd affinitás kromatográfia révén tisztítottuk. Ezután megvizsgáltuk a tisztított fehérjék in vitro aktivitásait.

A már ismert aktivitásokat vizsgálva megállapítottuk, hogy a HIRAN mutáns fehérjéink rendelkeznek ATPáz aktivitással, és képesek kettősszálú DNS-függő helikázként működni. Ezen kívül a vad típusú fehérjéhez hasonlóan poliubikvitilálják a PCNA fehérjét az MMS2-UBC13 fehérjekomplex jelenlétében. Ezekből az eredményeinkből arra következtettünk, hogy az általunk létrehozott HIRAN mutáns HLTF fehérjék szerkezetileg épek maradtak, a mutáció csak a HIRAN doménre volt hatással. Kimutattuk azonban, hogy a mutáns fehérjéink nem rendelkeznek replikációs villa-visszafordító aktivitással. Így in 
vitro kísérleteinkből azt a következtetést vontuk le, hogy a HLTF fehérje HIRAN doménje a replikációs villa-visszafordító aktivitásért felelős.

\section{HIRAN domén mutáns HLTF fehérjék in vivo aktivitás tesztelése}

Megvizsgáltuk, hogy a HIRAN domén mutációja, vagy hiánya milyen hatással van a HLTF fehérje sejten belüli aktivitására. A HLTF mutáns humán sejtkultúrák érzékenyek különböző DNS-károsító ágensekre. Megállapítottuk, hogy a HIRAN domén mutáns HLTF fehérjék UV sugárzás hatására a sejtmagba jutnak, mégis a HIRAN domén mutáns fehérjéket expresszáló humán sejtek érzékenysége megegyezik a HLTF-et shRNS segítségével csendesített formában tartalmazó sejtek érzékenységével.

BrdU comet esszé segítségével kimutattuk, hogy a HLTF-et shRNS-el csendesített formában tartalmazó sejtekben UV sugárzás hatására a replikáció lassabban megy végbe, mint a vad típusú sejtekben. A HIRAN domén mutáns fehérjéket expresszáló sejtekben a replikáció szintén lassabban megy végbe, mint a vad típusú sejtekben.

Eredményeinkből arra következtettünk, hogy a HLTF fehérje HIRAN doménje létfontosságú a fehérje bármelyik aktivitásához in vivo. 


\section{HIRAN domén DNS-kötő tulajdonságai}

Vad típusú és kettős pontmutáns HIRAN domént élesztőben túltermeltettünk, majd tisztítottunk. A tisztított HIRAN doménekkel gél shift kísérletben kimutattuk, hogy a pontmutáns domén nem képes DNS-t kötni. A vad típusú domén esetében kimutattuk a kölcsönhatást egyesszálú DNS-el és replikációs villa szubsztráttal. A HIRAN domén kettősszálú DNS-el nem hatott kölcsön. Kompetíciós kísérlettel megállapítottuk, hogy a HIRAN domén a replikációs villát köti erősebben.

A HIRAN domén deléciós HLTF fehérjének nincs replikciós villa-visszafordító aktivitása. Azonban vad típusú HIRAN doménnel összekeverve újra megfigyeltük a vad típusú HLTF-re jellemző aktivitást.

Ebből, és az eddigi kísérletekből azt a következtetést vontuk le, hogy a HIRAN domén felelős a HLTF replikációs villa-visszafordító aktivitásáért, valamint, hogy a HIRAN domén megléte nélkülözhetetlen a HLTF normál funkciójának betöltésében in vivo. A HIRAN domén egyrészt azért lehet felelős, hogy a HLTF fehérjét az elakadt replikációs villához irányítsa, ott a villához kösse, és képessé tegye a villa visszafordítására, másrészt lehetővé tegye egyéb funkcióinak betöltésére. 


\section{Köszönetnyilvánítás}

Szeretnék köszönetet mondani Dr. Haracska Lajosnak, hogy 2006-ban csatlakozhattam a csoportjához. Köszönöm a lehetőséget, a sok rám fordított energiát, türelmet, és a rengeteg segítséget.

Köszönettel tartozom Pintér Lajosnak, aki bevezetett a kutatás sokszor nehéz, de csodás világába. Köszönöm a rengeteg átadott szellemi és technikai tudást, a sok jó tanácsot, a szakmai és baráti beszélgetéseket, és hogy megmutatta azt a szemléletet, amivel igazán jó kutatóvá válhat az ember.

Köszönöm továbbá Fekete Ildikónak, Kovács Katalinnak és Nótári Péterné Icunak a technikai segítséget, amivel könnyebbé tették a labormunkát.

Köszönöm Yathish Jagadheesh Acharnak a szakmai segítségét és hasznos tanácsait!

Szeretném megköszönni Juhász Szilviának, Mórocz Mónikának, Tick Gabriellának és Burkovics Péternek a kísérletekben és a cikkek megírásában nyújtott segítséget!

Köszönettel tartozom továbbá laborunk egykori és jelenlegi tagjainak, hogy mindenben segítettek, amiben tudtak.

Különösen köszönöm Döme Lilinek, Frittmann Orsolyának és Tóth Róbertnek, hogy mindig számíthattam rájuk, mind szakmai, mind egyéb tekintetben, és amiért mindig örömtelivé tették a néha nehéz pillanataimat. 
Köszönöm külföldi partnereinknek, Česlovas Venclovasnak, Dante Neculainak, Sirano Dhe-Paganonnak és Shunichi Takedának a segítséget.

Szeretnék köszönetet mondani egykori tanáraimnak, akik erősítették bennem a természettudományos pálya iránti szeretetemet. Kiemelném gimnáziumi tanáraimat, Lampert Zoltán biológia, Smiger András kémia és fizika tanáraimat, valamint Dr. Boros Imre Miklós, Dr. Maróy Péter és Dr. Török Tibor egyetemi tanáraimat, akiknek köszönhetően ragadott meg véglegesen e tudományterület szépsége.

Köszönöm Dr. Honti Viktornak és Dr. Pankotai Tibornak, amiért rövid határidővel elvállalták dolgozatom bírálatát!

Köszönöm továbbá az SZBK Genetikai Intézet vezetőinek, és minden tagjának, akik valamilyen módon hozzájárultak dolgozatom megírásához, valamint szakmai segítséget nyújtottak.

Végezetül szeretném megköszönni családomnak, rokonaimnak, és barátaimnak, hogy mindig mellettem álltak, és mindenben számíthattam rájuk. Köszönöm! 


\section{Saját közlemények jegyzéke}

\section{A dolgozat alapját képező közlemények:}

Achar Yathish $^{\#}$, Balogh David $^{\#}$, Neculai Dante ${ }^{\#}, J u h a s z$ Szilvia, Morocz Monika, Gali Himabindu, Dhe-Paganon Sirano, Venclovas Ceslovas, Haracska Lajos. Human HLTF mediates postreplication repair by its HIRAN domain-dependent replication fork remodelling. NUCLEIC ACIDS RESEARCH \&: pp. inpress. (2015). IF: $9.11 \quad$ MTMT: 2933791

Burkovics P, Sebesta M, Balogh D, Haracska L, Krejci L. Strand invasion by HLTF as a mechanism for template switch in fork rescue. NUCLEIC ACIDS RESEARCH 42:(3) pp. 1711-1720. (2014) IF: 9.11

MTMT: 2549960

\section{További közlemények:}

Achar YJ, Balogh D, Haracska L. Coordinated protein and DNA remodeling by human HLTF on stalled replication fork. PROCEEDINGS OF THE NATIONAL ACADEMY OF SCIENCES OF THE UNITED STATES OF AMERICA108:(34) pp. 14073-14078. (2011) IF: 9.67 MTMT: 1921828

Juhasz S, Balogh D, Hajdu I, Burkovics P, Villamil MA, Zhuang Z, Haracska L. Characterization of human Spartan/C1orf124, an ubiquitin-PCNA interacting regulator of DNA damage tolerance. NUCLEIC ACIDS RESEARCH 40: pp. 10795-10808. (2012) IF: 9.11

MTMT: 2106876 